\title{
ATTILA VANDRA* \\ THE INFLUENCE OF PSYCHOLOGICAL GAMES ON MENTAL HEALTH IN EDUCATION
}

(Received: 9 June 2007; accepted: 5 September 2007)

The percentage of those who have mental health problems is much higher in the group of people who chose supporting occupations (teachers, psychologists, etc.), than in the whole society. Teachers need personal development as psychotherapists do. In Rumania the realisation of such a project would involve many difficulties. Because of a misbelief (education is unidirectional) there is an expectation, indeed a very strong one, that teachers adopt the role of the Rescuer, somebody who tries to solve other people's problems, even if the other refuses help. Experimental data confirm the tendency of teachers to adopt the role of the Rescuer. Adopting this role can have two negative consequences. 1) It negatively affects the maturation process of the child and 2) it becomes a source of psychological games in which participants make efforts both to suffer and to make others suffer. For prevention, an education for maturation is necessary, which is possible only in assertive conflict solving and in OK-OK life positions. Different psychological schools are analysed. This life position is adopted by humanist psychology and by transactional analysis. The promotion of humanistic psychology or transactional analysisbased pedagogy in Rumania can be helpful, but is not the only solution and is not the solution. The problem is that humanistic Gordon pedagogy is unknown, and there are no certified transactional analysis trainers in Rumania today.

Keywords: mental health, school, transactional analysis, psychology, Gordon pedagogy, games, education, maturation, assertive, prevention, Rumania

Die Wirkung psychologischer Spiele auf die mentale Gesundheit in der Erziehung: Menschen, die mit mentalen Problemen zu kämpfen haben, entscheiden sich häufiger für einen helfenden Beruf (Lehrer, Psychologe etc.). Auch Lehrer benötigen Selbsterfahrung, wie sie für Psychotherapeuten vorgeschrieben ist. Deren Einführung in Rumänien stößt jedoch auf großen

*Attila Vandra, Transsylvanian Debate Association (EDE), str. Berzei 2B, ap. 20, RO-500276 Braşov, Rumania; vandraattila@rdslink.ro. 
Widerstand. Aufgrund des Irrglaubens, Erziehung sei ein unidirektionaler Prozess, stehen die Lehrer unter Druck, die Rolle des Retters zu übernehmen. Ein Retter versucht, nach eigenen Maßstäben die Probleme eines anderen gegen dessen Widerstand zu lösen. Die Ergebnisse von Experimenten bestätigen die Tendenz von Lehrern, als „Retter“ zu handeln. Die Rolle des Retters hat zwei negative Konsequenzen: Sie bremst die Reifung des Kindes und fördert die Entstehung von psychologischen Spielen. Bei diesen Spielen bemühen sich die Partner darum, selbst zu leiden bzw. den Partner leiden zu lassen, daher bedeuten diese eine ernsthafte Gefährdung der mentalen Gesundheit der Schule. Als Vorbeugung wird ein der Reifung des Kindes förderlicher Erziehungsstil verwendet, der nur mit Hilfe des assertiven Umgangs mit Konflikten und einer OK-OK-Haltung möglich ist. Der Autor kommt zu dem Schluss, dass diese Lebenseinstellung inbesondere von der humanistischen Psychologie und der Transaktionsanalyse vertreten wird. Die Einführung einer auf diesen psychologischen Schulen basierenden Pädagogik in Rumänien ist eine verlockende Möglichkeit, aber nicht die einzige und nicht die Möglichkeit. Die Schwierigkeit besteht darin, dass die Gordon-Pädagogik in der rumänischen Fachliteratur unbekannt ist, während die rumänische Transaktionsanalyse noch in den Kinderschuhen steckt.

Schlüsselbegriffe: mentale Gesundheit, Schule, Transaktionsanalyse, Psychologie, GordonPädagogik, Spielereien, Erziehung, Reifung, assertiv, Prävention, Rumänien

\section{Introduction}

It is the aim of this article to analyse psychological games, one of the main factors that have a negative influence on mental health in schools, and looks to possible ways of preventing mental health problems in Rumania.

According to the literature, school 'exerts a powerful influence on mental health.'

The main role of mental health is to exert a positive influence on a large part of a community in order to ensure health preserving behaviour. School has a decisive role in mental health. ... The goal of mental health is to ensure optimal intellectual, emotional, physical and social development and to shape a healthy personality that has a load-bearing capacity and is able to carry out its social obligations. ... The goals of mental health are basically identical with the most important values, goals and human-centred aspirations of our society, and are also the same as the targets of pedagogy. Starting from these premises we consider the school an environment where mental health ideology and methodologies are applicable.

(BAGDY \& TELKES 2002, 21-22) ${ }^{1}$

The main roles of mental health can be divided into three prevention levels:

- Primer prevention tries to eliminate those factors, which are the causes of illness or behaviour dysfunction. There are two groups of such activities:

1. Health promotion activities, which increase resistance against harmful influences.

2. Prevention of specific illnesses.

${ }^{1}$ Translation by the author of this article. 
- The role of secondary prevention is the early recognition of illnesses.

- The role of tertiary prevention is the treatment in order to prevent further injuries (BAGDY \& TELKES 2002, 21).

\section{Mental health difficulties in Rumanian schools}

Increasing the mental health potential of a school does not imply transforming it into a therapeutic institute, it only means ensuring a better environment, favourable for the positive development of a child's personality. The main role of school is primary prevention. Is this role a real role or only a declarative one? May the school be a source of mental health problems? What changes are needed in order to help schools perform this role?

By the school environment we mean a social environment rather than a material one, in which the child spends an important part of his/her life, and where the guiders (not the decision-makers!) are the teachers, who have an important influence even on the dynamics of children's groups. The question arises: what type of mental health environment do teachers create in order to preserve children's mental health?

The statistics presented by TRINGER (2005) are thought-provoking. Mental health problems are more frequent among those who choose supporting occupations (teachers, psychologists, physicians, social workers), than in the control group, the whole society. Considering professional harm in addition (teachers have a stressful job) we will reach a pessimistic conclusion. ITAA (International Transactional Analysis Association) and EATA (European Association of Transactional Analysis) recommends:

PTSC recommends personal therapy over the period of training in order to experience the application of Transactional analysis and to ensure the trainee can apply TA from a largely script-free stance and without harmful behaviour.

(English EATA Handbook 2004)

Psychotherapists need supervision and personal development and so do teachers. Supervision and mentoring of beginners is possible but it is not a well-functioning system in Rumania. Personal development is based on knowledge achievement, not on character changes, to avoid 'harmful behaviour'. Psychological examination has only two possible results: able/not able. A teacher can be psychologically able to work in school, but can have harmful tendencies (an under-pathological level of narcissism, an over-controlling tendency, aggresivity, a tendency of victimisation, etc.). These tendencies can be kept at a minimum level by personal development.

However, realising such a project would involve many difficulties. If in the USA each person has his/her own therapist, Rumania represents the other extreme. In other East-European countries the situation is not much better. Should anyone ask for qualified help in educational matters they risk being labelled. Consequently many people in need of help prefer rationalisation: 'I have no psychological problems, but my students get an inadequate family education.' 'My child is not insane, only uneducable.' It is appropriate to mention a personal experience here: 
It happened when I was making desperate efforts to organise the first 'School for Parents' (a project which succeeded only at the third attempt due to a lack of candidates). I was waiting for my turn at the ski lift, in Poiana Brasov. Near me was a naughty boy of 7 or 8 , together with his mother. She was making futile attempts to discipline him. I was amused by the boy's behaviour and I could not help telling him my favourite Rumanian quibble: "Clearly, the slogan "a clever boy is not obedient" fits you!' His mother exploded: 'At school they teach you a lot of useless things, but nobody teaches you how to educate your child!' 'I have been trying to organise a School for Parents for weeks ...' I thought she would inquire further, but she turned her back on me. Needless to say, this was not the only experience of this kind I was faced with when I tried to organise a guiding course for parents. Everybody whom I shared my ideas with said: 'Wow, what a wonderful idea!' 'So will you come?' 'Oh no, my child is an adolescent ...' (No comment).

Teachers, who would be willing to attend personal development training or (horribile dictu!) go to psychotherapy, first need to admit to themselves that they might need help. But this would mean the risk of being labelled, of having their competence questioned by their colleagues, superiors, the parents and even by the children who are educated in such a social environment. The transfer of responsibility is safer. In this kind of environment, in such a society, any aspirations to new horizons are obstructed.

It is thought provoking why more people with mental health problems (not insane!) choose supporting occupations (e.g. teaching). During a conference organised by the Program for Prevention of Domestic Violence I was shocked by the fact that the majority of social workers and psychologists involved in this program had been victims of domestic violence. Assuming an active role in this program they were trying to rescue the helpless child, they once were, who had no support, when they experienced domestic violence. At first sight this type of solving problems by sublimation (ALLPORT 1954) seems to be praiseworthy, but it hides the risk of falling in the trap of the Rescuer. ${ }^{3}$

There is a difference between the Helper and the Rescuer. The Helper gives another person requested support in order to solve problems. He/she gives help only in the way and only to the extent the other person requests. The Helper considers the other an OK person, with OK problems, and with abilities to solve them, needing support. The Rescuer tends to forget that what is 'too good' is not good any more, and gives more help than is required. But he/she cannot give more help than the other requests without discounting the helped person or his/her problems, without treating $\mathrm{him} / \mathrm{her}$ as non-OK. (I am giving you more support than you requested, because it is my interest to solve your problems as it is better for me, because you aren't able to solve them, or because you are bad, and I have to change you). To quote MÉRÖ László: 'The altruist does good basically to his/her own altruism' $(1996,165)$.

\footnotetext{
2 'Văd că şi sloganul tău este că un copil cu minte nu-i cuminte!'

${ }^{3}$ The capital used is not accidental. It shows that it is not a real rescuing, but more a role-play. Rescuer is a characteristic term in transactional analysis, but can be adapted also out of this theory, like in education. Rescuer as a concept of transactional analysis will be defined later in this article.
} 
Apparently there is a basic qualitative difference between the Helper and the Rescuer. If we regard a Helper-helped person it is an OK-OK relationship, while a Rescuer-rescued person is an I am OK-you are not OK one (STEWART \& JOINES 1987/2004). I regard the division of supporting persons in Rescuers and Helpers as a dichotomy. However, there are situations in which it is easy to make the difference ('I want to help you' 'But I need no help!' or 'I shall help you even if you do not want me to'). In most cases, the situation can be characterised by: 'I want to give you more help than you request' or 'Your help is useful, but I need less help than you want to give me!' In such a situation the question arises: To what extent am I a Rescuer and to what extent am I a Helper? It is not my intention that will count but rather the role in which the helped person will perceive me.

If I tidy my daughter's room it is questionable whether the act was motivated by surprising her, or rather, by my intention to surprise her. In most cases both motivations are present in different amounts. The first is a Helper, the second is a Rescuer motivation.

If my daughter has five problems (A, B, C, D, E) to solve, and asks me to help her solve problem A and B and I solve only A I am a Helper, who has given insufficient support. If I solve A and B I am the ideal Helper. If I solve A, B and C she can react: 'Wow! Thanks!' ('You are my Helper!'), but she also can say: 'Who has asked you for such a help? Do you think I am not able to do it?' ('You are a Rescuer!'). If I solve all her problems I am beyond doubt a Rescuer. Discounting also has different degrees (MELLOR \& Sigmund in STEWART \& JOINES 1987/2004, 126-31) and it is not a problem of ontology. Even a 'May I help you?' apparently 'pure Helper' question hides an amount of discounting ('I think you need help, because I think that you are not able to solve it alone') but less than: 'Let me do it instead of you!' The difference between a Helper and a Rescuer is more a quantitative problem than a qualitative one.

Making an analogy with participants of the Program for Prevention of Domestic Violence and applying the conclusions to the teachers can be a misleading analogy (HORVÁtH 2002). We can accept as very plausible that there are such persons who choose to become teachers in order to 'buy' the love and acceptance of society in exchange for giving their knowledge to others. This can also be done in an egoistic way, playing the role of the Rescuer.

\section{Why do teachers become Rescuers?}

It is an almost generally accepted misbelief, that the educator 'educates' the 'uneducated' child. It is a misbelief, because education is the result of an interaction, which has an impact on both the character of the 'educated' child, and that of the educator. (Let us compare parents and childless couples). The analogy with the teaching process is a false one, because the 'educated person' does not start with a 'blank page' like the 'taught person' does. A person, who finds himself/herself in an unknown situation will react in some way (acceptable or not) even if he/she has never been taught what the 
'correct' reaction might be. A person who has never been taught or has not learnt has no knowledge. For example he/she cannot say a word in English (VANDRA 2007).

The previous misbelief is a trap, which practically invites the teacher to become a Rescuer. ('It is my obligation to change him, to make him better.') In reality, even the instruction process is more than a single source phenomenon. If we state that the child 'was taught by the teacher' we neglect the importance of learning by discovering. Without that, the knowledge of mankind would show a diminishing tendency. Any knowledge resulting from a child's effort of discovering is beyond the teacher's control. Such a process cannot be controlled by a teacher and perhaps can only be influenced to a certain extent. The teacher can only hope that his/her students will discover the advantages of hard work as a consequence of his/her strictness. Admittedly, in this way, a part of his/her students will discover the 'advantages' of cheating. By his/her strictness a teacher might unintentionally teach some of his/her students to cheat (VANDRA 2007).

Because of the previous misbelief (education is a unidirectional process, and the educator's obligation is to educate the 'uneducated' child) society exerts considerable pressure on the teacher forcing him/her to become a Rescuer, to solve the child's problems. Children are considered by society not OK (uneducated), who need to be changed to become OK (well educated) whether they want it or not. Society is discounting the children. It considers them ignorant of their own needs. Hence the necessity to 'rescue' them arises. No wonder that even teachers with little or no inclination towards becoming Rescuers might fall into the trap. (I do not wish to state that all teachers have the urge to become Rescuers, only that the phenomenon exists!) The teacher, who wants to avoid this trap, is in an even more difficult position, if his superiors utter such expectations. The conflict resulting from the familiar position of 'You have to do this' - 'I do not want to' is transformed into a competition during which the teacher and the child evolve into contenders or competitors. The regularities of these competitions are described by the mathematical game theory as the 'Chicken!' game and the 'Dollar Auction Game' (MÉRÖ 1996; VANDRA 2006). The essence of these games is, that he/she who gives up will lose. Because of the permanent expectations of society and superiors, teachers are more likely to give up, assuming the role of the Rescuers. Conformity (ARONSON 1972; ASH 1956) is another pressure on teachers to accept the role. The fact that most colleagues accept this, puts pressure on the them to do the same. $25.9 \%$ of the subjects of Asch's well-known experiment gave up their own correct opinion only because they saw that the others had done the same (AscH 1956). In such a situation the role of the Rescuer can be considered an occupational hazard.

\section{Discrepancies between need and educational goals}

The role of the Rescuer assumed by teachers is the source of many problems at school. It affects mental health because it obstructs the child's process of maturation and is a source of unnecessary conflicts. As we have seen, the Rescuer is in reality a Helper, who exaggerates his/her role of giving support. 
The question is, whether our theoretical premises are correct or not? Can we demonstrate by experiment the tendency of the educators (teachers and parents) to adopt this role? Can we demonstrate the egoistic tendencies in education? (Aiding the child in such a way that is advantageous for the educator, not necessarily for the child.) Are there discrepancies between what would be necessary for the child and what the educator wants to achieve? The educators' targets in education may be measured by asking them about their own goals. What is necessary in education can be weighed up after carefully considering the differences between the knowledge and abilities of an adult and those of a child.

The goal of education is not only the socialisation of the child, and to teach the child a socially accepted form of behaviour. There are two further goals: self-realisation (realising his/her own interests) and maturation. Beyond reaching physical and biological maturity, this process is much more a psychological one, the way from a childlike dependence due to an adolescent-like 'independence' to the mature adult-like interdependence, the way from irresponsible child-like behaviour to responsible adult behaviour, from a child's sense of guilt and/or shame to an adult way of assuming responsibility, from dichotomic (either-or) thinking (who is the guilty one?) to differentiated thinking (which is my part of responsibility and which is yours?), from selfcentred symbolism ${ }^{5}$ to the ability to empathise, etc. (VANDRA 2007). Another misbelief is that self-realisation is the opposite of socialisation, and the role of education is to teach the child to adopt the expectations of society giving up his/her own egoism. There are two types of self-realisation: the assertive kind and the egoistic kind. It is only the latter that is not in keeping with socialisation. Furthermore, there are two types of socialisation: assertive and obedient, and it is only the obedient socialisation

\footnotetext{
${ }^{4}$ There is a lot of contradiction in literature about shame, sense of guilt and responsibility. According to FOSSUM \& MASON (1989), 'While guilt is a painful feeling of regret and responsibility for one's actions, shame is a painful feeling about oneself as a person'. KovÁCS (2007) makes a distinction between adequate and inadequate sense of guilt. However, guilt is a label, with negative connotations and is associated with deserving punishment and shame. Who commit guilt, cannot consider themselves as OK persons. Defining shame and guilt as opposite terms is based on a myth created by FREUD (1977) that the role of Superego is to motivate people to respect social rules by creating sense of guilt. It is a myth, because it neglects the role of Superego after committing a guilt, its role in the law of the irreversible mistake (ALLPORT 1954; ARONSON 1972). The freudian model is based on the presupposition that the only way to motivate a person is punishment, which is true only on the first level of Kohlberg's ethical development: the obedience and punishment orientation (KOHLBERG et al. 1983). On higher levels of ethical development there are alternatives for motivation by creating responsibility. The responsibility of a person is his/her consciousness that he/she, and not another person, has to have a pro-active behaviour to prevent, to solve or to repair a problem. The main similarity between shame and sense of guilt is that their consequence is the discounting of the guilty person, who is not OK (STEWART \& JOINES 1987/2004, 91-95; F. VÁRKONYI, unrehearsed). The main difference between sense of guilt (and/or shame) and responsibility is that responsibility does not discount. A responsible person is OK. The fundamental thesis of humanist psychology and transactional analysis is that everybody is OK (BERNE 1972; 2000a, 99-104; HARDAI 2004, 11-17). What KovÁCs (2007) defines as 'adequate sense of guilt' seems to be responsibility.

${ }^{5}$ Term proposed by J. PIAGET and B. INHELDER instead of 'egocentric' $(1966 ; 2004,55)$. By their opinion a newborn cannot be named egocentric because he is not able to take into account the point of view of another person.
} 
that is not in line with assertive self-realisation. An obedient child will become an obedient adult. Obedience is not a positive adult characteristic, it should not be a goal in education. (There are some situations when it is, for example in the situation when we follow the indications of a physician, but these examples are only exceptions. In most cases normal adult-adult relationships are symmetrical ones. Obedience is a characteristic form of behaviour related to dependency.) Children have to be educated towards assertive self-realisation, this is a real need in education. Maturation is not a process that automatically comes with age, with biological maturity. Mature behaviour has to be learned and practised, and it is a different goal in education (VANDRA 2007).

\section{Experimental data sustaining Rescuer tendency of educators}

Obedience is an egoistic expectation of a Rescuer. The obedient child is a comfortable partner in conflict. The immaturity of the child is also a need of the Rescuer-like educator. Immature children are comfortable partners, because they need much intervention from the educator. What we can expect from a Rescuer is to promote exaggerated socialisation (obedient socialisation) suppressing self-realisation and maturity. Can this prognosis be sustained by experimental data?

33 persons (15 primary school teachers and 18 secondary school teachers, 28 women and 5 men, aged 22-55, 70\% also parents) from School No. 5 in Braşov, participants at the training 'Democracy and Tolerance in School' (2005) were given the following questions:

I) Write down your ten most important targets in education, and those ten things you most want to avoid by education (e.g.: I want my students to become 1 . . . [Positive trait] 2 . . . etc., but I will do everything to prevent them from 1 . . . [Negative trait] 2 ... etc.).

II) Write down five pairs of traits which underline the differences between a child and an adult (e.g.: 1. While the child is ... [child trait] the adult is ... [corresponding adult trait] 2 ... etc.).

After eliminating the wrong answers (personality traits that cannot be influenced by education in the first exercise and not corresponding pairs in the second one) the answers were divided into three groups: socialisation, self-realisation and maturation, and the percentage of the answers was calculated. If the characteristic corresponding to the educational target helps the person to be more easily accepted by society (e.g. adaptable, sincere, polite) it was considered to be socialisation. If the characteristics help to accomplish the children's own interests (e.g. courageous, ambitious) it was considered self-realisation, and if it was achieved in the process of maturation (for example independence, responsibility) it was considered to be maturation. Characteristics which could be considered as being part of more than one category (for example assiduity) were introduced in both. ${ }^{6}$ The results showed the following distribution (Table 1):

\footnotetext{
${ }^{6}$ It was not verified if the participants of the study perceived maturation as teachable or a phenomenon related to biological maturation. The study started from the premise that teachers, specialists in education, know what is educable and what is not.
} 
THE INFLUENCE OF PSYCHOLOGICAL GAMES ON MENTAL HEALTH IN EDUCATION 191

Table 1

The distribution of the answers of subjects

\begin{tabular}{lccc}
\hline Category & Socialisation & Self-realisation & Maturation \\
\hline Target in education & $54.55 \%$ & $32.33 \%$ & $13.11 \%$ \\
$\begin{array}{l}\text { Educational necessities } \\
\text { (child-adult differences) }\end{array}$ & $10 \%$ & $20 \%$ & $70 \%$ \\
\hline
\end{tabular}

Although the study can be criticised because of the small number of experimental subjects, and the representation of the distribution, the results confirm our prediction about the Rescuer tendency. The fact that all subjects acquired a higher percentage of socialisation than of maturation and self-realisation in the first exercise confirm the tendency in education to attach greater importance to socialisation, neglecting maturation and self-realisation. However, it may also be a deficiency of the method. We must also notice that the deficiency of the method may lead back to linguistic impacts. We have more terms in our language for socialisation than for maturation and for selfrealisation.

In order to analyse possible linguistic impacts in the former study, a survey was conducted analysing the relative frequency of words and expressions related to socialisation, self-realisation and maturation in the vocabulary of everyday language, in psycho-pedagogical language and in the language used by different psychological schools. 20,000 words were analysed from the Hungarian-English Dictionary (BORÓK 2000), for everyday language, 5,700 words and expressions from the Rumanian-Hungarian Psycho-pedagogic Dictionary (FODOR 1999) for psycho-pedagogic language, 2,100 terms in The Concise Dictionary of Psychology (STADT 1998) for the language of psychologists, 197 terms of transactional analysis in the Transactional Analysis Dictionary (F. VÁRKONYI, unrehearsed), 210 terms in the glossary of terms in The Gestalt Approach \& Eye Witness to Therapy (PERLS 1973; 2004, 242-246) for the language of Gestalt psychology, 32 terms in the the glossary of terms in Az Elfogadás Müvészete $^{8}$ (HARDAI 2004, 19-25) for the language of humanistic psychology, 390 terms in the glossary of terms of A Gyermek Pszichológiai Fejlödése (VAJDA 1999, 245249) for the language of child psychology.

After eliminating the redundant terms (which could not be classified as socialisation, self-realisation or maturation) the percentages of terms in socialisation, selfrealisation and maturation were calculated. While the absolute percentages have no

\footnotetext{
${ }^{7}$ This study was not made with the purpose of writing an article. The aim was to show the participants of the training their own tendencies. The author of the present article has made several such trainings, but this is the only one from which he has the statistical distribution of the answers. In other cases the distribution was similar and he met one single person, a child psychologist, who considered maturation more than socialisation.

${ }^{8}$ The Art of Acceptation

${ }^{9}$ The Psychological Development of the Child
} 
significance, the relative ones show the relative interest for the above mentioned three categories and are comparable (see Table 2).

Table 2

The distribution of terms in different 'languages'*

\begin{tabular}{|c|c|c|c|c|c|}
\hline$N r$ & Language & $\begin{array}{c}\text { Classifiable } \\
\text { terms }\end{array}$ & $\begin{array}{l}\text { Socialisation } \\
(\%)\end{array}$ & $\begin{array}{l}\text { Self-realisation } \\
(\%)\end{array}$ & $\begin{array}{l}\text { Maturation } \\
\text { (\%) }\end{array}$ \\
\hline 1. & Everyday language & 1568 & 57.78 & 29.46 & 12.76 \\
\hline 2. & $\begin{array}{l}\text { Pedagogical } \\
\text { language }\end{array}$ & 812 & 56.16 & 26.97 & 16.87 \\
\hline 3. & $\begin{array}{l}\text { Psychological } \\
\text { language }\end{array}$ & 469 & 51.60 & 26.65 & 21.75 \\
\hline 4. & $\begin{array}{l}\text { Gestalt psychology } \\
\text { main terms }\end{array}$ & 115 & 56.52 & 32.17 & 11.31 \\
\hline 5. & $\begin{array}{l}\text { Transactional } \\
\text { analysis main terms }\end{array}$ & 159 & 45.91 & 28.93 & 25.16 \\
\hline 6. & $\begin{array}{l}\text { Humanistic psychol- } \\
\text { ogy main terms }\end{array}$ & 30 & 33.33 & 40.00 & 26.67 \\
\hline 7. & $\begin{array}{l}\text { Psychology of child } \\
\text { development main } \\
\text { terms }\end{array}$ & 200 & 47.50 & 21.00 & 31.50 \\
\hline
\end{tabular}

* The standard deviation is $\pm 1.85 \%{ }^{10}$

Comparing these percentages to the answers of the subjects of our study, it can be concluded that psycho-pedagogical language seems to have a high influence on the educational goals of subjects (first exercise - Table 1), but it has no influence on the educational needs (second exercise - Table 1). The distribution of answers in both exercises cannot only be explained by linguistic influences. If language has an influence it must be present in both exercises.

A very similar distribution concerning psycho-pedagogical language can be found in everyday language and in Gestalt psychology. Between these data there are less than two standard deviations, so it cannot be concluded that the answers of the subjects are, to a greater extent, influenced by everyday or psycho-pedagogical language (subjects answered as parents or as teachers), only that language could have an influence on the answers. It cannot be concluded how strong the tendency is for teachers to become Rescuers rather than for parents, only that the tendency exists.

\footnotetext{
${ }^{10}$ Absolute values - calculated from the distribution of values between groups of 70 terms.
} 
In the language of general psychology the sensible higher percentage of maturation can be mentioned (more than four standard deviations). This percentage is much higher if we analyse terms used in transactional analysis, in humanistic psychology and in child development psychology. These languages have a more balanced percentage for all categories (percentage under $50 \%$ for socialisation, higher than $25 \%$ for maturation).

The difference of the distribution of terms can be explained by the SAPIR-WHORF Hypothesis (in FORGAS 1986; 2000, 138-139) In linguistics the SAPIR-WHORF hypothesis states that there is a systematic relationship between the grammatical categories of the language a person speaks and the way that a person both understands the world and behaves. Culturally essential objects, conditions, and processes are usually defined by a plethora of words, while things that cultures perceive as unimportant are usually assigned one or two words.

The language of the Eskimo people contains more words about snow, south-east Asian languages contain more expressions about rice than European languages, and medical language contains more expressions about tumours than everyday language. Starting from this premise, an increased percentage of terms in a language shows the increased interest in a phenomenon, a lower one a decreased one, the distribution of terms in psycho-pedagogical language shows an increased interest in socialisation and less of an interest in maturation. A mature person has no need to be rescued, so this distribution sustains the Rescuer tendency in school education. The fact that the real need in education is different is sustained by the different distribution of terms in child psychology. We can find similar distributions in two 'rebel' psychological schools, which start from the premise that the client is not a non-OK patient, or an 'uneducated' child, who needs to be rescued, but he/she is an OK person who can be helped to take his/her own mature adult decisions for his/her life.

The presented data show that it is not the language that influences the distribution of educational goals, the relationship is at least a two way process between parents and children: the educational interest also influences the language. In this way, the answers given by the subjects of the presented study confirm but do not conclusively prove the exaggerated tendency of teachers for socialisation.

The exaggerated high percentage of maturation in the second exercise has at least two explanations. The first is the relatively low number of independent and well classifiable answers, which allows an increased dispersion. The other one is that socialisation and maturation have a different rhythm. A 10-year-old child is relatively well socialised, but the maturation process is only at the beginning. In this way the easiest observable differences between children and adults are the maturation ones.

The increased percentage of words about self-realisation in pedagogical language can also be explained by many expressions related to ability building, one of the main roles of the school, not by the interest for self-promoting behaviour in conflicts. Ability building is one of the main goals in education, but self-realisation also contains efficient behaviour in conflicts. This part of self-realisation is neglected in school education.

A study made by SZEKSZÁRDI (2002) also sustains the tendency of teachers towards exaggerated socialisation. While the opinion of psychologists and students of pedagogic profile is that a withdrawn child represents a greater educational problem 
than one who shows troublesome behaviour, the opinion of active teachers is the opposite. The author draws the conclusion that teachers have the tendency to solve their own problems, thus they have a greater interest in solving the problem of troublesome children because a withdrawn child does not disturb them directly.

This data also confirms the exaggerated tendency for socialisation of teachers, but the data is not incontestable. Further studies are necessary.

The child's interest is to develop a personality with a balanced rapport between socialisation, self-realisation and maturation, respectively. If the teacher is more interested than is necessary in socialisation, it will lead to conflict. The teacher who tries to solve the problem of socialisation with children will inevitably become a Rescuer, who discounts children and their problems. ('I have taken the decision, you now have to be obedient, or you will be labelled as bad.')

\section{Why is the Rescuer-like behaviour a real mental health problem?}

From the point of view of individual mental health, an egoist, an obedient or an immature dependent personality is a pathological phenomenon. Abnormal socialisation, self-realisation or maturation can become the sources of mental health problems in society. As we have seen, school has a role in primary prevention. Creating a wrong balance among the three mentioned factors can become the source of mental health problems.

The Rescuer, who knows what is better for the child and tries to solve the child's problems from his/her own point of view, expects obedience from the child. Any reaction from the child is compared with expectations and receives the label of 'obedient' or 'rebel'. For the child who tries desperately to defend his/her own interests, two possibilities remain: to become selfish or to become obedient. The only decision the child can take is whether to be obedient or not. This is an immature decision, thus the maturation process is also affected. A child labelled as immature will behave immaturely and his/her maturation will be repressed.

Rescuer-like behaviour can also become a source of unnecessary conflicts, if the child chooses to be a rebel. Such conflicts usually follow the model of the 'Dollar Auction Game' (VANDRA 2006). In most cases the 'auction' ends paying more than double the price for the dollar; so the winner of the dollar also loses (MÉRÖ 1996, 1128). In such conflicts much more energy is invested than the situation is worth.

The misspent energy is the smaller problem in such conflicts. Much more dangerous is the possibility of transformation of conflicts not solved correctly into psychological games. 'Psychological games are repetitive, stereotypical forms of human behaviour with a predictable end, following predetermined patterns and rules, and have a pay-off of negative (racket) feelings' (PARR 2002, 39). These games have motivations out of awareness and sado-masochistic characteristics: all participants make efforts to suffer and to make the others suffer. They become dependent on these games, they cannot avoid them and thus suffering becomes repetitive. After each round they become more motivated to repeat the game with the same script. The names of these 
games are suggestive: 'Kick me!' 'I Got You Son of a Bitch!' 'I'm Trying Only to Help You ...' 'You See, I Tried, but ...' 'Wooden-leg' 'Mother, I'm in Pain . . .' etc. (BERNE 1964; 2000, 247-252; F. VÁRKONYI 2001, 21-36). Transactional analysis commonly known as TA to its adherents is a theory of human personality, a theory of social behaviour and a comprehensive system of psychotherapy founded by Eric Berne, MD (1910-1970) during the late 1950s (English EATA Handbook 2005, 2). Transactional analysts base their treatment of psychological diseases on the treatment of psychological games. With their specific methods they teach their patients how to avoid these games. According to Eric BERNE (1964; 2000, 82), psychological games are played in different degrees. The first degree game is not harmful, representing the savour in our lives. Players are socially accepted by the environment. The second-degree games are those that the players would like to conceal, though they may not cause irreversible damage. They are disturbing for their environment. Third-degree games are those that may lead to severe harm to one or more of the parties concerned.

A 3-4-year-old child does not play games, these games are learned later (STEWART \& JOINES 1987/2004) Kindergarten and school have a decisive role in the formation of these games even if they originate mostly at home. The methods used by transactional analysts are based on developing in their patients mature, adult behaviour. In their opinion, those who have immature personalities tend to play more intensive games. These arguments lead to the assertion that in schools the chronic, high degree psychological games are among the most harmful phenomena for mental health. Psychological games can be prevented by appropriate behaviour of teachers, while inappropriate behaviour may be the source of such games. Consequently, teachers have a great responsibility in prevention.

In psychological games players can have three typical roles: the Rescuer, the Persecutor and the Victim forming the Drama triangle. Each participant assumes one of these roles while playing the game. At a given point the roles are interchanged. If we manage to recognise one of these roles (assumed by any player) then in all possibility we have identified a psychological game (KARPMAN in STEWART \& JOINES 1987/2004).

If a teacher tries to be a Rescuer he/she will provoke the children to accept the role of a Victim who needs to be rescued. In cases when children refuse this role, they will perceive the Rescuer as a Persecutor. For example, the children want to do something independently. The Rescuer teacher tries to 'help' them. If the children do not want to be helped - refusing the role of the helpless Victim - they perceive their educator as a Persecutor, who does not let them work independently. Being persecuted, the children feel they have the right to answer insolently, persecuting their teacher. The teacher feels he/she is transformed into a Victim, so it is his/her right to overreact, punishing and persecuting the children, who will tell their parents an exaggerated story of a Victim, aiming at being rescued. Parents rescue their children persecuting the teacher, who again becomes a Victim, feeling that it is justifiable to take revenge, persecuting the children ... What can children learn from such a game?

If the children accept the role of the helpless Victim who needs to be rescued, they may conclude that the responsibility for their problem is the teacher's. They notice 
that the role of the Rescuer is a necessity for the teacher. The children will be rewarded for letting the teacher rescue them ('Good children'). Consequently, the next time they will play the role of the helpless Victim again in order to be rescued. After each round they become more and more irresponsible (Dollar Auction Game) and it becomes the teacher's responsibility to rescue them. At a given point this exaggeratedly helpless behaviour becomes disturbing for the teacher, ('I help them willingly, but if it is always my obligation... There are others in this classroom, who need my help too!'), who will feel persecuted, so he/she will put pressure on the children, persecuting them. The children ask to be rescued by their parents ... Is it better? It all started from rescuing. Such an environment, characterised by reactive behaviour, is not enough for mental health.

What we do not see in such games is responsible pro-active behaviour: 'I have made a mistake, I know what to do next time!' Neither the teacher, nor the child or the parents assume the responsibility for their own mistakes, they always blame 'the other one'. The 'justifiable' reactive strategy has never changed to the 'efficient' proactive one. The way out from these games is the same as the educational need: education towards responsibility, towards maturation. How can we educate for maturation?

Education has five sources.

1. The example given by the educator can be a model of behaviour ('I do what you do').

2. The expectation of the educator is another model to be copied ('I do what you say').

3. An exaggerated expectation can induce the opposition, and the result will be the opposite of what the educator expects ('I do the opposite to what you say').

4. He/she can also discover forms of behaviour to solve his/her problems without having any model ('Thinking is free! I do what I think is useful!')

5. Everything needs to be exercised. Behaviour, in order to be corrected, needs the possibility to exercise, and positive feedback (feeling of being successful). Negative feedback motivates to avoid, not to repeat.

In order to discover an efficient educational model, we need guidance as to what to do and also what to avoid.

Thus we shall educate children for maturation by:

1. Giving them a positive model of mature behaviour assuming adult-like responsibility of the educator.

2. Expecting mature behaviour: to take decisions, to act independently, to judge their own actions themselves and to accept responsibility and consequences of their decisions and actions.

3. Avoiding constraining the child to avoid opposition. By being empathic, we do not antagonise them (assertive conflict solving).

4. In an environment of freedom, they are free to discover efficient behaviour experiencing good and bad variants, if they are not given judgemental but sincere feedback. ('I am glad you have done this.' 'Your behaviour disturbs me.')

5. In the same environment they have the opportunity to exercise mature decisions, and the positive feedback of the successful experiments that will teach them 
positive, socially accepted, but also self-promoting behaviour (assertive conflict resolutions). This does not mean letting them do what they want, only up to the point where they interfere with other people's freedom of action.

Children will not be educated in the required direction in the following circumstances:

1. They are given negative models. For example the educators do not accept their part of responsibility in conflicts, accusing them of everything.

2. They are expected to show immature behaviour: obedience or letting them do what they want without any conditions (laissez-faire education).

3. They are constrained from taking mature decisions in risky situations or in situations which exceed their problem solving abilities. Such situations will induce their opposition, they will be prevented from maturation.

4. The children may discover efficient methods to manipulate others to solve their problems, or to escape responsibility or consequences, in which case they will not want to be mature. It will be more convenient for them to remain immature. Immaturity has advantages.

5. If these 'immature' tactics are repetitively efficient, they will prefer to avoid maturation. The same happens if they have no opportunity to take free decisions, because the educator takes the decisions before them (Rescuer educator).

As positive factors we may identify mature adult forms of behaviour, conditional freedom, assertive conflict solving and avoiding drama triangle roles. As negative factors we identify the typical drama triangle roles, constrain or unconditional freedom and competitive (loser/victorious) conflict resolutions.

Let us follow two examples to see the difference between the education for maturity and the Rescuer behaviour.

Rescuer behaviour of the mother:

- Jancsi, stop playing and go and study! (Rescuer, trying to resolve the child's problem. Child is not OK.)

- But Mom ... (= Mother, please understand me ... The child tries to play the role of the Victim, of being rescued. Mother is OK only if she rescues him.)

- No buts! Go and study! (Persecutor, child is not OK.)

- You never understand me! (= 'You are bad, I am a Victim', but he is persecuting his mother. Mother is not OK.)

Child's conclusion: 'It is not my obligation to know when I have to start studying.'

Education for maturity:

- Jancsi, I see you are absorbed in playing. I do not want to fight with you, because you have not finished your lessons! ('I am sure you will understand me' = You are OK. Presents her own problems. She is not a Rescuer.)

- But Mom ... (= Mom, understand me ... Child tries to play the role of the Victim, for being rescued. Mother is OK only if she rescues him)

- I know, it is hard to interrupt the game. But, I repeat, I do not want to fight with you, because you have not finished your lessons! (Understanding. Child is OK, but mother does not give up solving her problem.) 
- Only a little more! (Mother is more OK, she understands him. He tries to get more understanding. His behaviour is only partial of Victim's.)

- And if you do not finish your lessons in time, will you give up watching your favourite cartoon? (Solution is unacceptable for mother. Asks for another solution from the child. Child is OK, he is able to give mature solutions.)

- Ten minutes. And call me when the 10 minutes are over! Please! (Acceptable decision for mother. Child asks for help, and will get it.)

- OK by me! (Everybody is OK.)

It is important to make a clear distinction between a sense of guilt and assuming mature responsibility. In order to understand the difference, let us study a two-yearold child and an adult who has made a mistake. The child has an either/or way of thinking ('I am either bad or good' respectively 'Either I am the bad one or you are'). A child is not able to take into account the intentions in ethical decisions, only the results of the actions. From a child's point of view it is a greater mistake to accidentally break an expensive flowerpot than breaking a cheaper one intentionally. A child starts from the premise that a person who is mistaken has to be punished and is afraid of punishment. For him/her the biggest punishment is to be rejected by his/her parents, not the physical punishments (PIAGET \& INHELDER 1966; VANDRA 2007). His/her main interest is how to find a strategy to be accepted by the parents even if he has made a mistake. Crying, accepting that he/she is mistaken, promising he/she will never do it again, asking for forgiving, rationalisations, transferring of responsibility will be discovered as efficient strategies. One of the most efficient ones is: 'You see I am punishing myself being ashamed, I do not deserve more punishment'. The sense of guilt is not only the awareness of being mistaken, it is associated with the mentioned strategies and feelings.

We can also see such reactions at adults. The child has an either/or way of thinking ('I am either bad or good' respectively 'Either I am the bad one or you are'). ('I am bad because ... but good because ...' respectively 'My mistake is that ... and yours is that ...'.) There are two ways of thinking, as is shown in the above examples. The adult theoretically is capable of both, a child only of the either/or one. In intensive conflicts adults also have either/or thinking. If an adult person is capable only of the either/or thinking, it is a sign of immaturity or of pathology (paranoic behaviour). An adult is able to prefer a solution instead of a punishment. He/she can assume responsibility for his actions. Assuming responsibility means that he/she is aware of what changes his behaviour needs in order to prevent a similar conflict, to solve the problems and thus the conflict itself respectively to repair damages (BIRKEHNBIHL 2000; VANDRA 2007). Assuming responsibility is not necessarily associated with the feeling of being guilty. 'I can look for a better solution in order to help you even if I was not guilty. If I did not find the best solution it does not mean that I am guilty.'

Hurting somebody by opening a door will create cognitive dissonance. It creates a conflict between the desire to know yourself as a good person, and the fact that you have hurt the other (FESTINGER 1957). You can escape in more ways from it: transferring responsibility ('Why did you stand next to the door?'), rationalisation ('It did not injure you did it?'), sense of guilt ('Sorry, don't blame me, I did not know, that you 
were next to the door...') and assuming responsibility ('I know, I hurt you. Next time I shall enter more carefully. But please don't stand right behind the door, it is not transparent. May I see your arm?').

Another distinction has to be made between punishment and negative consequences. A child, who makes a bad decision, has to support the negative consequence of his/her decision. He/she cheats, he/she gets a $1^{11}$. He/she decided to cheat, he/she knew the rules, so he/she has to accept the consequences. Punishment is given by the educator. The adequacy of it can be questioned, it can be considered exaggerated. 'You were noisy, come to the blackboard' 'But ...' 'No buts!' Teacher considers that the child is behaving inadequately, he/she needs to be disciplined and 'rescues' him/her persecuting him/her 'in his/her interest'. (Did the child have justified motives to be noisy?)

It is well-known that punishment is not an efficient educational tool but it is a tool (GORDON 1974, 1975; VANDRA 2007). Eliminating punishments from schools without exchanging it for another type of motivation is a dangerous decision. Teachers are lacking in the means of maintaining discipline in schools. It is not true, that nothing has happened in this sense, but it happened mostly on a theoretical level. Education is more an ability, than knowledge. It is similar with the situation when we give the definition of the laws of Thales and Pithagoras without exercising, and we expect the students to solve problems, using the mentioned laws.

Teachers need more to form abilities than to get theoretical knowledge in psychology. They also need personal development. The role of personal development is to recognise tendencies which can be harmful in their activity.

\section{Education for maturation in different psychological schools}

Different schools of psychology, in many cases, have contradictory opinions. Each school provides useful knowledge, but teachers do not need to decide who was right: Skinner, Freud, Rogers or Piaget (VANDRA 2007). They need skills in efficient conflict solving. Tringer shows that in psychotherapy it is not the chosen technique that determines the efficiency of a therapist, but certain personal characteristics of the therapist, like congruency, the ability to have an OK-OK relationship with the client, the ability to empathise and of accepting without prejudices (TRINGER 2005).

The Rescuer teacher wants to change the children who are not OK, without being empathic towards their problems ('They are doing this only because they are bad'). Accepting the analogy between efficient characteristics of psychotherapists and efficient teachers we can conclude that efficient teachers must have OK-OK relationships with children, so the Rescuer behaviour is harmful in education.

Many conclusions of behaviourism are useful knowledge, but the basic question ('How to change the child's behaviour?') is in contradiction with the previous conclusions. Behaviourism is considered an obsolete theory (FROMM 1973).

\footnotetext{
${ }^{11}$ In Rumania marks are from 1 to 10 (10 is the best). To pass, a student must have at least 5.
} 
Freudian and neo-Freudian psychoanalysis can make teachers understand many phenomena in the subconscious of the child, but their methods, though useful in psychotherapy, have little practical advantages for a teacher. A teacher is not a therapist, school is not a therapeutic institute, and there is no need to transform it into one. The only role of the teacher is to make recommendations to parents in case a child needs therapeutic help.

The Gestalt school is more individual-centred. Some techniques of Gestalt have also been applied in other schools of psychology, as in transactional analysis (STEWART \& JOINES 1987/2004). The 'two chairs method' can also be useful in education for empathy in the classroom. Communication techniques are very useful in conflict solving. But this theory considers the client to be a patient who is not $\mathrm{OK}$.

Psychodrama methods can be useful in educational hours but provide less useful methods in everyday activities.

Carl Rogers was the first psychologist who started from the point that those who come to therapy are not patients, but clients. (TRINGER 2005). They do not need to be changed, they need help to develop. Humanistic psychology was a radically new departure. Based on his work, new trends in pedagogy appeared. Some sources label them child-centred pedagogy. One of the best-known schools was Gordon pedagogy (GORDON 1974, 1975; F. VÁRKONYI \& VÍZI 2007), which had a great impact worldwide. More than one million parents and teachers participated in Gordon training, acquiring useful skills in assertive conflict solving. Gordon pedagogy has changed people's mentality in education in the USA. Naturally Gordon pedagogy also has its opponents (DOBSON 1994, 1997). It is not an 'universally good' method, it has its limits. On the one hand, it is like a more advanced technology, and applying it incorrectly has its own risks. On the other hand, it is very useful in promoting co-operation, but becomes useless and even harmful if children do not want to co-operate and conflicts grow into competitions (rational games), or into chronic, high degree psychological games. In such games Gordon pedagogy has to be substituted for methods based on game theories (F. VÁRKONYI \& VÍZI 2007).

Transactional analysis is another theory that declares from the start that everybody is OK. Even if the child's behaviour is unacceptable, he/she is an OK person, who has to be respected (PARR 2007, 18-19). A person who behaves inadequately has a problem and by solving it he/she will change his/her behaviour. Gondos Anna has a motto: 'Nobody is stupid because everything around is OK. There must be a reason for his/her less than proper behaviour. ${ }^{, 12}$ Transactional analysis gives good theoretical support for education for maturity, and can help teachers with useful communication skills in avoiding the repetition of chronic games. As they start from similar premises (for example everybody is OK) transactional analysis and Gordon pedagogy can be complementary.

\footnotetext{
${ }^{12}$ It is an approximate translation of an untranslatable expression: 'Senki sem jódolgában hülye. Annak oka van, ha valaki nem megfelelően viselkedik.' The source of quotation: Vízi Beáta on a Gordon pedagogy training.
} 
Apparently, the mathematical game theory is not a psychological one, but studies the most efficient decisions in conflicts. The link with psychology is that some games are logical traps (e.g. 'Prisoner's Dilemma', 'Chicken!', 'Dollar Auction Game', etc.) in which the most efficient decisions are based on psychological considerations. VANDRA (2006) has found the link between the mathematical game theory and transactional analysis, describing the laws of transformation of rational games into psychological ones. In this way the mathematical game theory becomes a complementary theory for transactional analysis, and may give theoretical support in prevention of transforming co-operation into competition. Conclusions of the mathematical game theory give theoretical support to the methods of Gordon pedagogy, demonstrating for example why symmetrical OK-OK relationships are more efficient in repetitive conflicts than asymmetrical OK-non-OK ones and give theoretical support to understand the difference between 'to win' and 'to triumph', between real co-operation and games respectively show when Gordon pedagogy methods have to be changed by transactional analysis ones (when we can state that games become so irrational that rational motivations are inefficient) (VANDRA 2006). The models used are very helpful to understand when in a conflict the need appears for a strategy change (when a conflict situation is transformed into another, a different one which needs a different strategy), and can also teach abilities to help maintaining control over conflicts. It can efficiently be combined with transactional analysis and client-centred pedagogy showing the limits of the former theories. Using mathematical game theory in personal conflicts and combining it with psychology is a new initiative (VANDRA 2006, 2007).

\section{Possible solutions}

In my opinion child-centred pedagogy is the wrong definition for client-centred pedagogy. The essence of OK-OK philosophy is not the attention to the child's needs. Whoever tries to apply Gordon pedagogy as child-centred philosophy puts the child above the teacher, which is a very dangerous tendency. If classical pedagogy was teacher-centred, (which is good from the point of view of the teacher) or result-centred (that is what we need for efficiency), child-centred pedagogy is the opposite extreme (what we have to do for the welfare of the child). Gordon pedagogy was criticised mainly because of these tendencies. If children have rights, and the teacher does not, their mental health will be affected. A teacher, feeling cast in the role of Victim, will initiate games in self-defence.

Well-applied Gordon pedagogy is also a powerful method for the self-defence of the teacher. It is not only the child's, but also the teacher's rights which have to be respected. A mental health-promoting school is only possible if respect is mutual.

A possible way to promote mental health in schools in Rumania is by promoting humanistic psychology based pedagogy (Gordon pedagogy is only one of them). Courses providing information about this are not enough. Practical training with less theoretical knowledge is more useful. Furthermore, if a teacher participates in one such course, the probability is high that after trying the new way he/she gives up, and 
returns to his/her classical methods (ANDERSON 1996; 2005, 183-84). Introducing a new pedagogy is like painting the room: first we have to remove the old paint, making a lot of dirt. Some of those who try to apply it, will be frightened and will return to their old methods ('I have tried, but' ... psychological game).

\section{To return to difficulties in Rumania}

It is necessary to form a community of teachers who apply these methods, to exchange their experiences, to keep alive the motivation to change. It is a difficult inner fight to change oneself. But it is possible, and it is worth investing energy in it. Game theory application in education can also be useful. In Rumania, the problem is that transactional analysis communities can only be found in two cities (in Bucharest and in Timişoara), and the first certified transactional analysts will sustain their certification exams only next year. Transactional analysis has 4 domains of application, but only two of them are under development. TA is practically not applied in education. ARAT (Rumanian Association of Transactional Analysis) is not yet interested in investing energy in educational development. The application of the mathematical game theory in education is a new idea. Only 46 sites are found by Google for 'mathematical game theory' + pedagogy + education. Most of these files are found because of accidental, simultaneous presence of these expressions.

Gordon pedagogy is also relatively unknown in Rumania. Only three Rumanian sites contain the name of Thomas Gordon, the author of TET and PET. (There are more persons named Thomas Gordon.) Promoting Gordon pedagogy may have a positive influence on Rumanian schools. If we try to promote it as 'the correct pedagogy' we lose its essence. The translation of his books in Rumanian would also be useful.

The promotion of humanistic psychology or transactional analysis-based pedagogy in Rumanian schools may be a solution, but it is not the only one. We must not forget that games are mainly of home origin, and it is hard to expect a mature behaviour from a child, who tries to play his/her favourite games he/she has got used to at home. But if we are successful we can have an important contribution to promoting a healthy environment at school.

Promoting this pedagogy would also bring more success in family education. Teachers who apply these principles efficiently can have an important influence on parents. Parents' Schools organised by the Gordon model should have an impact but we have to apply them carefully, to avoid the mistakes made in the USA.

A personal development training system has to be organised. It may be shocking, but more experienced teachers need more personal development. The increasing tendency to play psychological games is a professional hazard and personal development may prevent these tendencies.

Improving mental health in school will have a positive effect on the mental health of society in general. This has to begin in school. 


\section{References}

AllPORT, G.W. (1954) The Nature of Prejudice (Reading, MA: Addison-Wesley).

ANDERSON, J.A. (2005) A kommunikációelmélet ismeretelméleti alapjai, trans. G. WILHELM (Budapest: Typotex) Hungarian trans. of Communication Theory, Epistemological Foundations (New York \& London: Guilford, 1996).

Aronson, E. (1972) The Social Animal (New York \& Oxford: W. H. Freeman and Company).

AsCH, S. (1956) 'Studies of Independence and Conformity: A Minority of One against a Unanimous Majority', Psychological Monographs 70 (Whole no. 416).

BAgdy, E. \& J. TELKES (2002) Személyiségfejlesztö módszerek az iskolában (Budapest: Nemzeti Tankönyvkiadó).

BERne, E. (2000a) Sorskönyv, trans. B. EHMANN (Budapest: Háttér) Hungarian trans. of What do You Say After You Say Hello? (Beverly Hills, California: City National Bank, Robin Way and Janice Way Fahrlinger, 1972).

BERne, E. (2000b) Emberi játszmák, trans. Á. HANKISS (Budapest: Háttér) Hungarian trans. of Games People Play. The Psychology of Human Relationships (New York: Grove Press, 1964).

BoróK, J. (2000) Magyar-Angol kéziszótár (Kisújszállás: Szalay Könyvkiadó és Kereskedőház Kft.).

DoBSOn, J. (1994) Az akaratos gyermek (Budapest: Keresztyén Ismeretterjesztő Alapítvány).

Dobson, J. (1997) Fegyelmezz! Megéri! (Budapest: Keresztyén Ismeretterjesztő Alapítvány).

English EATA Handbook, section 7 (2004) retrieved December $11^{\text {th }} 2004$ from http://www.eatanews.org/index.php?option $=$ com_docman\&task=cat_view\&gid=30\&dir= DESC\&order $=$ date $\&$ limit $=5 \&$ limitstart $=15$.

English EATA Handbook, section 1 (2005) retrieved May $9^{\text {th }} 2005$ from http://www.eatanews.org/index.php?option=com_docman\&task=cat_view\&gid=30\&dir= DESC\&order $=$ date\&limit $=5 \&$ limitstart $=10$.

Festinger, L. (1957) A Theory of Cognitive Dissonance and Consumer Behaviour (Stanford: Stanford UP).

F. VÁRKONYI, Zs. (2001) Már százszor megmondtam . . (Budapest: Magyar Könyvklub).

F. VÁRKONYI, Zs. (unrehearsed) Transactional Analysis Dictionary.

F. VÁRKONYI, Zs. \& B. VíZI (2007) Már százszor megmondtam . . Gyerek és felnött játszmák az óvodában és az iskolában (workbook) (Budapest: Gordon \& TA).

FODOR, L. (1999) Dictionar Psihopedagogic Român-Maghiar (Cluj-Napoca: Educatio).

Forgách, J. (Forgas, J.P.) (2000) A társas érinkezés pszichológiája, trans. J. LÁszló (Budapest: Kairosz) Hungarian trans. of Interpersonal Behaviour: The Psychology of Social Interaction (Oxford: Pergamon Books Ltd., 1986).

Freud, S. (1977) Pszichoanalízis (Bucharest: Téka).

Fossum M.A. \& M.J. MASON (1989) Facing Shame: Families in Recovery (New York: W.W. Norton).

Fromm, E. (1973) The Anatomy of Human Destructiveness (New York: Holt).

GoRDON, T. (1974) T.E.T. - Teacher Effectiveness Training (New York: Wyden).

Gordon, T. (1975) P.E.T. - Parent Effectiveness Training (New York \& Scarborough, Ontario: Wyden).

HARDAI, S.I. (2004) Az elfogadás müvészete (Budapest: Akadémiai).

HorvÁTH, G. (2002) A vitatechnika alapjai (Cluj-Napoca: Scientia).

Kohlberg, L., C. Levine \& A. Hewer (1983) Moral Stages: A Current Formulation and a Response to Critics (Basel, NY: Karger). 
KovÁCs, Gy. (2007): A segitö kapcsolatok pszichológiája, retrived on August $29^{\text {th }}, 2007$ from http://www.communio.hu/plebania/konyvtar/szakdolg/szakd003.htm.

MÉRÖ, L. (1996) Mindenki másképp egyforma (Budapest: Tericum).

PARR, J. (2002) 'Individuation, Attachment \& Group Dynamics', Revista de psihologie aplicatã 3 (Timisoara: Universitatea de Vest din Timişoara).

PARR, J. (2007) AT 101: Introducere în analiza tranzacționalã (Bucharest: International Center of Transactional Analysis).

PERLS, F. (2004) A gestalt-terápia alapvetése. Terápia testközelböl, trans. É. DoBos (Budapest: Ursus Libris) Hungarian trans. of The Gestalt Approach \& Eye Witness to Therapy (Palo Alto, California: Science \& Behavior Books, 1973).

Piaget, J. \& B. INHELder (2004) Gyermeklélektan, trans. K. BENDA (Budapest: Osiris) Hungarian trans. of La Psychologie de l'enfant (Paris: Presses Universitaires de France, 1966).

STADT, D.A. (1998) The Concise Dictionary of Psychology (London \& New York: Routledge).

STEWART, I. \& V. JOINES (2004) TA aztăzi, o nouă introducere in analiza tranzacțională (Timişoara: Mirton) trans. of TA today: A New introduction to Transactional Analysis, 1987.

SzEKSZÁRDI, J. (2002) Konfliktusok pedagógiája (Veszprém: Veszprémi Egyetemi Könyvkiadó).

TRINGER, L. (2005) A gyógyitó beszélgetés (Budapest: Medicina).

VAJDA, Zs. (1999) A gyermek pszichológiai fejlödése (Budapest: Helikon).

VANDRA, A. (2006) 'The Link between the Mathematical Game Theory and Transactional Analysis: A New Way of Psychological Games Come into Being' Europe's Journal of Psychology, May, $12^{\text {th }} 2006$, retrieved May $13^{\text {th }} 2006$ from: http://www.ejop.org/archives/ 2006/05/the_link_betwee_1.html.

VANDRA, A. (2007) Neveljünk, de hogyan? (Braşov: Editor BL 49). 